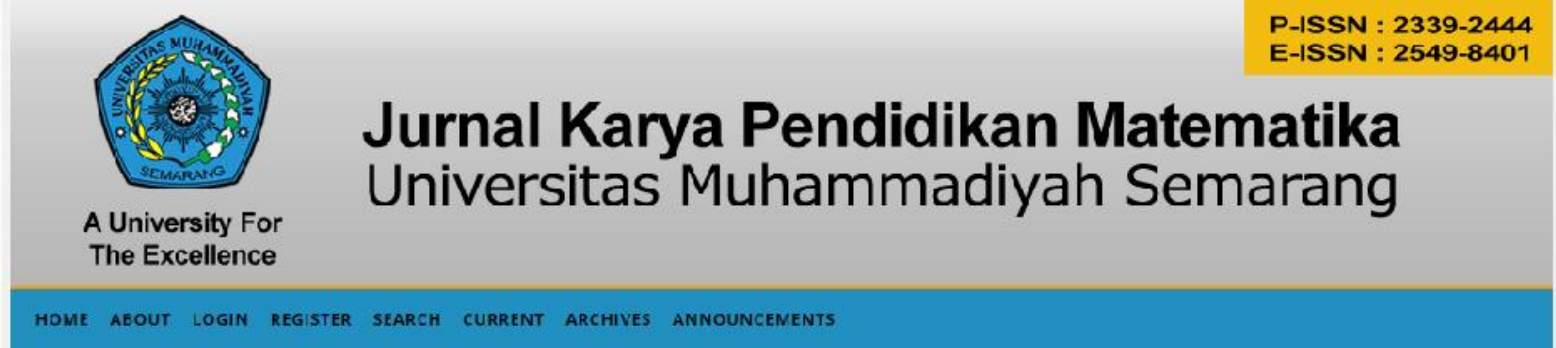

\title{
PERBEDAAN PEMAHAMAN KONSEP MATEMATIKA MENGGUNAKAN METODE TAI DAN PAIR CHECKS DITINJAU DARI MINAT BELAJAR
}

\author{
Limoi Ani ${ }^{1}$, Rahmat Winata ${ }^{2}$, dan Rizki Nurhana Friantini ${ }^{3}$ \\ $\underline{\text { limoi89898@gmail.com }}^{1}, \underline{\text { nata win89@yahoo.com }}{ }^{2}, \underline{\text { keyheart1315@gmail.com }}^{3}$ \\ ${ }^{1,2,3}$ Pendidikan Matematika, STKIP Pamane Talino, Ngabang, Indonesia
}

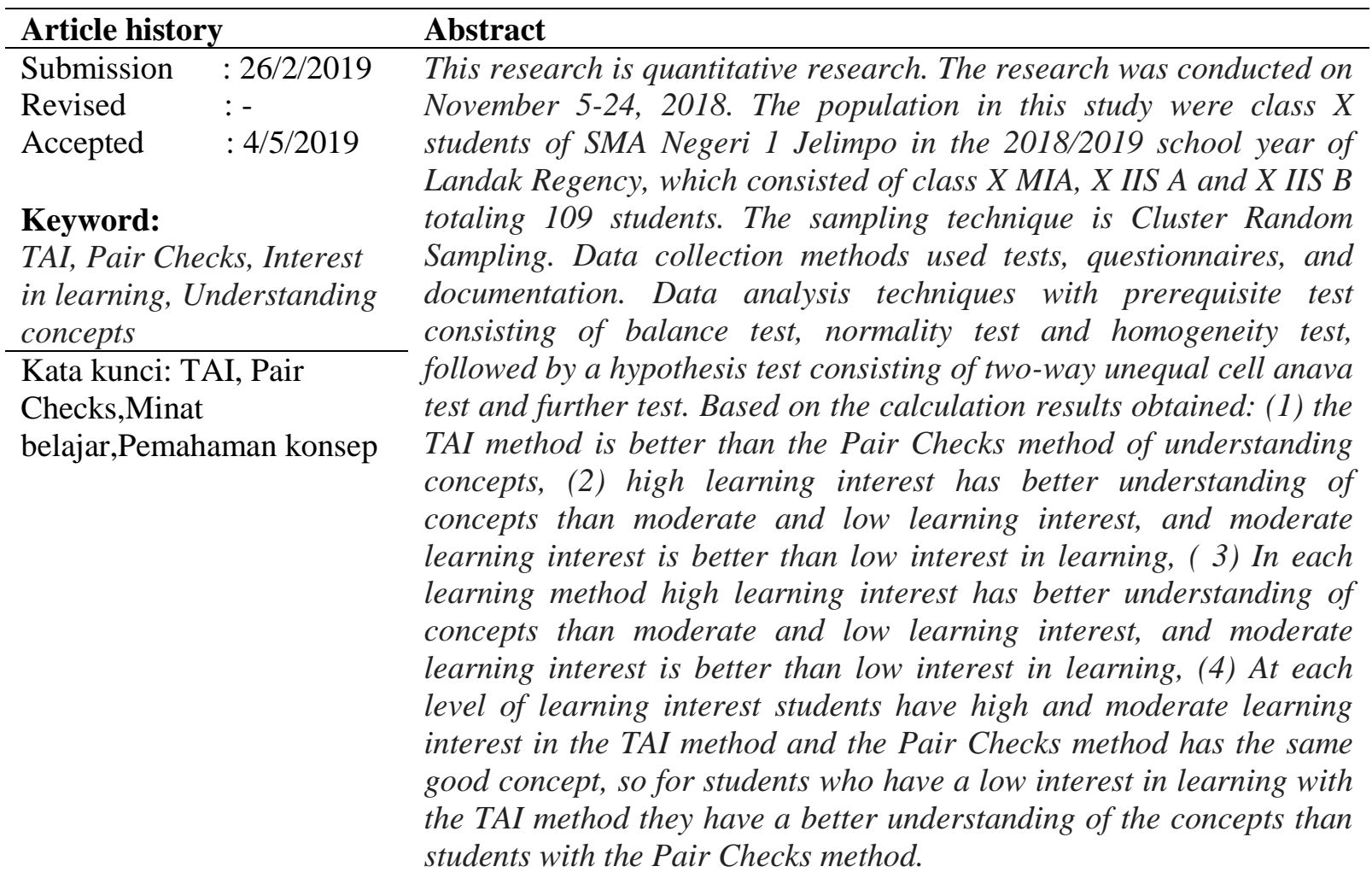

15

http://jurnal.unimus.ac.id/index.php/JPMat/index 


\section{Pendahuluan}

Matematika umumnya dikenal dengan keabstrakannya yang berangkat dari realita lingkungan manusia. Menurut Heruman (2013:4), pada pembelajaran matematika harus terdapat keterkaitan pengalaman belajar siswa sebelumnya dengan konsep yang akan diajarkan. Dalam matematika setiap konsep berkaitan dengan konsep lain dan suatu konsep menjadi prasyarat bagi konsep lain. Pemahaman konsep menurut Shadiq (dalam Yulita, 2016:37) merupakan suatu proses mengidentifikasi, memahami, memberi contoh atau bukan contoh suatu objek persoalan, dan mengadakan analisa terhadap permasalahan untuk kemudian ditransformasi ke dalam model matematika. Memperhatikan pentingnya siswa memahami konsep dalam pembelajaran matematika, maka perlu adanya usaha untuk mengatasi permasalahan yang berkaitan dengan pemahaman konsep matematika siswa tersebut.

Sebagai indikator bahwa siswa dapat dikatakan paham terhadap konsep matematika, menurut Susanto(2013:209) dapat dilihat dari kemampuan siswa dalam beberapa hal, sebagai berikut: 1) Mendefinisikan konsep secara verbal dan tulisan, 2) Membuat contoh dan noncontoh penyangkalan, 3) Mempresentasikan suatu konsep dengan model, diagram,dan simbol, 4) Mengubah suatu bentuk representasi ke bentuk lain, 5) Mengenal berbagai makna dan interpretasi konsep, 6) Mengidentifikasi sifatsifat suatu konsep dan mengenal syarat-syarat yang menentukan suatu konsep, 7) Membandingkan dan membedakan konsepkonsep.

Berdasarkan hasil observasi dan wawancara yang dilakukan di SMA Negeri 1 Jelimpo khususnya pada kelasX masih banyak ditemukan permasalahan mengenai kesulitan siswa dalam memahami konsep matematika.Siswa belum benar-benar memahami konsep dari suatu materi dan belum dapat menjelaskan kembali materi yang diperolehnya. Dilihat dari hasil rata-rata nilai ulangan harian siswa yang memperoleh nilai 40 dan belum mencapai kriteria ketuntasan minimum.

Suatu metode pembelajaran yang digunakan dapat mempengaruhi pemahaman siswa dalam pembelajaran, untuk mengatasi permasalahan tersebut dapat menggunakan metode-metode pembelajaran yang berbeda dengan metode pembelajaran yang biasa digunakan guru di sekolah yaitu metode pembelajaran Team AssistedIndividuallization (TAI).Menurut Suyitno (dalam Syah dkk, 2014:1231), model pembelajarankooperatif tipe Team AssistedIndividuallization (TAI) merupakanmetode

pembelajaranyangmenekankan pada penerapan bimbingan antar teman. Selanjutnya menurut Slavin (dalamHuda, 2015:200), model pembelajaran kooperatif tipe TAI merupakan sebuah program pedagogik yang berusaha mengadaptasi pembelajaran dengan perbedaan individual secara akademik.

Kemudian selain model pembelajaran kooperatif tipeTAI ada juga tipe Pair Checks.Menurut Huda (2015:211), metode pembelajaran Pair Checksmerupakan metode pembelajaran berkelompok antardua orang atau berpasangan. Metode ini menerapkan pembelajaran kooperatif yang menuntut kemandirian dan kemampuan siswadalam menyelesaikan persoalan. Metode ini juga melatih tanggung jawab sosial siswa, kerjasama dankemampuan memberi penilaian.Selain itu, model pembelajaran kooperatiftipe Pair Checksadalah metodepembelajaran di mana siswa salingberpasangan danmenyelesaikan persoalan yang diberikan (Herdian dalam Shoimin, 2013:119).

Selain faktor dalam pemilihan metode pembelajaran yang akan diterapkan kepada siswa, pemahaman konsep juga dipengaruhi oleh faktor lain yaitu minat belajar. Hurlock (dalam Friantini dan Winata, 2019:7) mengatakan bahwa 1) minat mempengaruhi bentuk dan itensitas cita-cita, misalnya orang yang menaruh minat matematika akan bercitacita menjadi ahli matematika, yang hebat, atau menjadi orang yang ahli dalam bidang matematika, 2) minat dapat berfungsi sebagai pendorong yang kuat, siswa yang berminat pada matematika akan terdorong untuk melakukan kegiatan yang berhubungan dengan matematika, 3) prestasi selalu dipengaruhi oleh jenis dan intensitas minat seseorang, siswa yang berminat pada matematika akan berusaha mendapat nilai yang bagus dalam matematika, 4) minat menimbulkan kepuasan, siswa cenderung mengulang kegiatan yang berhubungan dengan minatnya.Mengembangkan minat 
terhadapsesuatu pada dasarnya adalah membantu siswa melihat bagaimanahubungan antara materi yang diharapkan untuk dipelajari dengan dirinya sendiri sebagai individu (Darmadi, 2017:316).

Dari uraian di atas tujuan pada penelitian ini adalah untuk mengetahui(1) Manakah yang lebih baik pemahaman konsep siswa yang menggunakan metode Team AssistedIndividuallization (TAI) atau siswayang menggunakan metode PairChecks, (2) Manakah yang lebih baiksiswa yang memiliki minat tinggi,sedang atau rendah terhadap pemahaman konsep, (3) Pada masing-masing metode manakah yang lebih baik siswa yang memiliki minat tinggi,sedang atau

rendahterhadap pemahaman konsep, (4)

Pada masing-masing tingkat minat siswa manakah yang lebih baik metode Team AssistedIndividuallization (TAI) atau metode Pair Checks terhadap pemahamankonsep.

\section{Metode Penelitian}

$\begin{array}{ccccc} & \text { Penelitian ini } & \text { dilaksanakan } & \text { diSMA } \\ \text { Negeri } & 1 & \text { Jelimpo } & \text { Kecamatan Jelimpo }\end{array}$ Kabupaten Landak. Waktu pelaksanaan dilaksanakan pada tanggal 5-24 November 2018. Penelitian ini menggunakan penelitian kuantitatif dengan metode komparasi. Populasi pada penelitian ini adalah siswa kelas X SMA Negeri 1 Jelimpo Tahun Ajaran 2018/2019, terdiri dari kelas X MIA, X IIS A dan X IIS B yang berjumlah 109 orang siswa. Adapun sampel dalam penelitian ini adalah kelas X IIS A dan X IIS B yang berjumlah 76 orang siswa. Teknik pengambilan sampel yaitu ClusterRandom Sampling. Rancanganpenelitian menggunakan rancangan faktorial $2 \times 3$ dapat dilihat pada tabel 1 .

Rancangan Penelitian

\begin{tabular}{llll}
\hline \multirow{2}{*}{ Metode } & \multicolumn{3}{c}{ Minat Belajar } \\
\cline { 2 - 4 } & Tinggi & Sedang & Rendah \\
\hline$\left(\mathrm{a}_{1}\right)$ & $\left(\mathrm{b}_{1}\right)$ & $\left(\mathrm{b}_{2}\right)$ & $\left(\mathrm{b}_{3}\right)$ \\
\hline TAI $\left(\mathrm{a}_{1}\right)$ & $\mathrm{ab}_{11}$ & $\mathrm{ab}_{21}$ & $\mathrm{ab}_{31}$ \\
\hline PC $\left(\mathrm{a}_{2}\right)$ & $\mathrm{ab}_{12}$ & $\mathrm{ab}_{22}$ & $\mathrm{ab}_{23}$ \\
\hline
\end{tabular}

Teknik pengumpulan data dilakukan dengan menggunakan tes untuk kemampuan pemahaman konsep matematika, angket untuk minatbelajarsiswa dan dokumentasi. Jumlah soal tes yang diujicobakan berjumlah 10 butir soal dalam bentuk uraian dan 30 butirpenyataan untuk angket yang diujicobakan.
Uji instrumen tes yang dilakukan yaitu uji validitas isi yang diuji oleh 3 orang validator, terdiri dari dua orang guru matematika SMA Negeri 1 Jelimpo dan satu orang dosen Pendidikan Matematika. Uji reliabilitas menggunakan rumus Alpha dengan indeks $r_{11} \geq 0,70$. Tingkat kesukaran yang digunakan yaitu berkriteria sedang antara 0,31 0,70 . Sedangkan untuk daya beda antara 0,41 0,70 berkeriteria baik.

Kemudian untuk uji instrumen angket yang dilakukan yaitu uji validitas isi diuji oleh 3 orang validator terdiri dari dua orang guru bimbingan konseling dari SMP Negeri 1 Ngabang dan satu orang guru dari SMA Negeri 1 Jelimpo. Uji reliabilitas angket juga menggunakan rumus Alpha dengan indeks $\mathrm{r}_{11} \geq$ 0,70 dan uji konsistensi internal menggunakan rumus korelasi Product moment dengan kriteria $\mathrm{r}_{\mathrm{xy}} \geq 0,3$.

Teknik analisis data terdiri dari uji prasyarat meliputi uji keseimbanganmenggunakan uji t, uji normalitas menggunakan metode uji Lilliefors dan uji homogenitas menggunakan uji Bartlett. Kemudian uji hipotesisdengan menggunakan rumus analisis variansi dua jalan sel tak sama dan uji pasca analisis variansi menggunakan uji Scheffe.

\section{Hasil Penelitian dan Pembahasan}

Dari hasil uji coba instrumen tes pemahaman konsep matematika dan angket minat belajar, terpilih 5 butir soal yang dapat digunakan sebagai instrumen tes dan 30 butir pernyataan yang dapat digunakan sebagai instrumen angket.

1. Uji Prasyarat

a. Uji Keseimbangan

Pada tahap awal dilakukan uji keseimbangan terhadap kondisi awal siswa pada kelas $X$ di SMA Negeri 1Jelimpo. Uji keseimbangan ini dilakukan berdasarkan hasil ulangan harian siswa sebelumnya. Tujuan dilakukannya uji keseimbangan iniuntuk mengetahui kondisi sampel yang akan diberikan perlakuan dan tes yaitu pada kelas X IIS A dan X IIS B dengan syarat uji normalitas dan uji homogenitas.

Pada uji normalitas untuk uji keseimbangan pada kelas X IIS A diperoleh $\mathrm{L}_{\max } \quad 0,114<\mathrm{L}_{\text {tabel }}$ 0,144disimpulkan sampelberdistribusinormal, kemudian pada kelas X IIS B diperoleh $\mathrm{L}_{\max } 0,089<\mathrm{L}_{\text {tabel }}$ 0,144 sehingga dapat disimpulkan 
sampelberdistribusi normal. Dari

ujihomogenitas kemampuan awal diperoleh $\chi_{\text {hitung }}^{2}=0,309<\chi_{\text {tabel }}^{2}=3,841$ sehingga dapat disimpulkansampel berasal dari populasi yang homogen.

Hasil uji keseimbangan yang menggunakan uji $\mathrm{t}$ diperoleh $t_{\text {hitung }}=0,004$ dan $\frac{t_{0,05} ; 2 ; 74}{2}=1,993$ dengan daerah kritisnya adalah DK $=\{t \mid t>1,993\}$. Karena $t_{\text {hitung }}=$ $0,004 \notin$ DK maka dapat disimpulkan $\mathrm{H}_{0}$ diterima yang berarti populasi dalam keadaan seimbang.

\section{b. Uji Normalitas}

Setelah itu baru dilakukan uji analisis data untuk tes pemahaman konsep matematika dan angket minat belajar, hasil dapat dilihat pada tabel 2 sebagai berikut:

Hasil Analisis Uji Normalitas

\begin{tabular}{lcccc}
\hline $\begin{array}{c}\text { Uji } \\
\text { Normalitas }\end{array}$ & $\mathbf{L}_{\mathbf{m a x}}$ & $\mathbf{L}_{\text {tabel }}$ & Putusan & Kesimpulan \\
\hline Kelas TAI & 0,119 & 0,144 & $\begin{array}{c}\mathrm{H}_{0} \\
\text { diterima }\end{array}$ & $\begin{array}{c}\text { Berdistribusi } \\
\text { normal }\end{array}$ \\
\hline Kelas PC & 0,080 & 0,144 & $\begin{array}{c}\mathrm{H}_{0} \\
\text { diterima }\end{array}$ & $\begin{array}{c}\text { Berdistribusi } \\
\text { normal }\end{array}$ \\
\hline $\begin{array}{l}\text { Minat } \\
\text { Tinggi }\end{array}$ & 0,144 & 0,173 & $\begin{array}{c}\mathrm{H}_{0} \\
\text { diterima }\end{array}$ & $\begin{array}{c}\text { Berdistribusi } \\
\text { normal }\end{array}$ \\
\hline $\begin{array}{l}\text { Minat } \\
\text { Sedang }\end{array}$ & 0,152 & 0,167 & $\begin{array}{c}\mathrm{H}_{0} \\
\text { diterima }\end{array}$ & $\begin{array}{c}\text { Berdistribusi } \\
\text { normal }\end{array}$ \\
\hline $\begin{array}{l}\text { Minat } \\
\text { Rendah }\end{array}$ & 0,168 & 0,184 & $\begin{array}{c}\mathrm{H}_{0} \\
\text { diterima }\end{array}$ & $\begin{array}{c}\text { Berdistribusi } \\
\text { normal }\end{array}$ \\
\hline
\end{tabular}

\section{c. Uji Homogenitas}

Dari hasil analisis uji homogenitas diperoleh keputusan dan kesimpulan yang dapat dilihat pada tabel 3 sebagai berikut.

Tabel 3. Hasil Analisis Uji Homogenitas

\begin{tabular}{|c|c|c|c|c|c|}
\hline Sampel & $\mathbf{k}$ & $\frac{t}{x-\underline{t} h i t}$ & 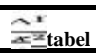 & Putusan & Simpulan \\
\hline Metode & 2 & 0,065 & 3,841 & $\begin{array}{c}\mathrm{H}_{0} \\
\text { diterima }\end{array}$ & $\begin{array}{r}\text { Variansi } \\
\text { homogen }\end{array}$ \\
\hline Minat & 3 & 2,212 & 5,990 & $\begin{array}{c}\mathrm{H}_{0} \\
\text { diterima }\end{array}$ & $\begin{array}{r}\text { Variansi } \\
\text { homogen }\end{array}$ \\
\hline
\end{tabular}

Dari tabel di atas dapat disimpulkan

bahwa masing-masing sampel berasal dari populasi yang homogen.

2. Uji Hipotesis

Dari hasil uji analisis variansi dua jalan sel tak sama diperoleh keputusan dan kesimpulan pada Tabel 4 berikut.

Tabel 4. Hasil Analisis Dua Jalan Sel Tak Sama

\begin{tabular}{lcccccc}
\hline \multicolumn{6}{c}{ Analisis Variansi Dua Jalan } \\
\hline Sumber & JK & dk & RK & Fobs & Fa & Putusan \\
\hline Metode & 94,22 & 1 & 94,22 & 7,65 & 3,98 & $\mathrm{H}_{0}$ \\
\hline
\end{tabular}

\begin{tabular}{lcccccc}
\hline (A) & & & & & & ditolak \\
\hline $\begin{array}{l}\text { Minat } \\
(\mathrm{B})\end{array}$ & 4307,92 & 2 & 2153,96 & 174,86 & 3,13 & $\begin{array}{c}\mathrm{H}_{0} \\
\text { ditolak }\end{array}$ \\
\hline $\begin{array}{l}\text { Interaksi } \\
(\mathrm{AB})\end{array}$ & 81,08 & 2 & 40,54 & 3,29 & 3,13 & $\begin{array}{c}\mathrm{H}_{0} \\
\text { ditolak }\end{array}$ \\
\hline Galat & 862,27 & 70 & 12,32 & - & - & - \\
\hline Total & 5345,49 & 75 & - & - & - & - \\
\hline
\end{tabular}

Dapat dilihat pada tabel 6 bahwa $\mathrm{H}_{O A}$ ditolak, $\mathrm{H}_{O B}$ ditolak, dan $\mathrm{H}_{O A B}$ ditolak. Dengan demikian dapat disimpulkan sebagai berikut.

a. $\mathrm{H}_{0 \mathrm{a}}$ ditolak dan $\mathrm{H}_{1 \mathrm{a}}$ diterima karena $\mathrm{F}_{\mathrm{a}}$ hitung $=7,65>\mathrm{F}_{\mathrm{a} \text { tabel }}=3,98$, maka terdapat perbedaan pemahaman konsep siswa antara penggunaanmetode Team AssistedIndividuallization (TAI) dan Pair Checks pada mata pelajaranmatematika pokok bahasan sistem persamaan dan pertidaksamaan linear.

b. $\mathrm{H}_{0 \mathrm{~b}}$ ditolak dan $\mathrm{H}_{1 \mathrm{~b}}$ diterima karena $\mathrm{F}_{\mathrm{b} \text { hitung }}$ $=174,86>\mathrm{F}_{\mathrm{b} \text { tabel }}=3,13$, maka siswa dengan masing-masing minat belajar,memiliki perbedaan pemahaman konsep pada mata pelajaran matematika pokok bahasan sistem persamaan dan pertidaksamaan linear.

c. $\mathrm{H}_{0 \mathrm{ab}}$ ditolak dan $\mathrm{H}_{1 \mathrm{ab}}$ diterima karena $\mathrm{F}_{\mathrm{ab}}$ hitung $=3,29>\mathrm{F}_{\mathrm{ab} \text { tabel }}=3,13$, maka terdapat interaksi pemahaman konsep antara penggunaan metodeTeam AssistedIndividuallization (TAI) dan Pair Checks ditinjau dari minat belajarpada mata pelajaran matematika pokok bahasan sistem persamaan dan pertidaksamaan linear.

3. Uji Lanjut

Berdasarkan hasil uji analisis variansi dua jalan dengan sel tak sama diperoleh bahwa $\mathrm{H}_{0 \mathrm{a}}, \mathrm{H}_{0 \mathrm{~b}}$ dan $\mathrm{H}_{0 \mathrm{ab}}$ ditolak sehingga perlu dilakukan uji lanjut pasca anava. Adapun hasil uji lanjut pasca anava atau komparasi ganda yang dianalisis berdasarkan hasil rerata marginal yang telah diperoleh dapat dilihat pada Tabel 5 sebagai berikut.

Tabel 5. Rerata Marginal Metode dan Minat Belajar

\begin{tabular}{|c|c|c|c|c|}
\hline Minat (B) & \multicolumn{3}{|c|}{ Minat Belajar } & Rerata \\
\hline Metode (A) & Tinggi & Sedang & Rendah & Marginal \\
\hline Metode TAI & 86,92 & 78,75 & 70 & 78,71 \\
\hline Metode PC & 86,56 & 77,50 & 65,20 & 76,42 \\
\hline Rerata & 86,74 & 78,13 & 67,60 & 77,56 \\
\hline
\end{tabular}


Marginal

a. Komparasi ganda antar baris

Uji analisis ini dilakukan antar dua metode, maka untuk antar baris tidak perlu dilakukan uji lanjut pasca anava cukup dengan melihat rerata marginal dari metode pembelajaran. Berdasarkan tabel rerata marginal diperoleh rerata pemahaman konsep siswa padapelajaran matematika yang menggunakan metode TAI adalah 78,71 dan pada metode PC adalah 76,42 Jadi dapat disimpulkan bahwa pemahaman konsep siswa yangmenggunakan metode TAI lebih baik dari siswa yang menggunakan metode PC.

b. Uji komparasi ganda antar kolom

$$
\text { Hasil uji komparasi }
$$

gandaantar kolom sebagai berikut.

1) $\mathrm{F}_{\text {hitung }} \mu 1$ vs $\mu 2=247,62>\mathrm{F}_{\text {tabel }}=6,26$ maka $\mathrm{H}_{0}$ ditolak. Pada nilai rerata marginal siswa yang memiliki minat belajar tinggi memperoleh rerata 86,74 sedangkan rerata siswa yang memiliki minat belajar sedang adalah 78,13. Sehingga dapat disimpulkan bahwa pemahaman konsep siswa yang mempunyai minat belajar tinggi lebih baik dari siswa yang mempunyai minat belajar sedang.

2) $\mathrm{F}_{\text {hitung }} \mu 1$ vs $\mu 3=1105,74>\quad \mathrm{F}_{\text {tabel }}=$ 6,26 maka $\mathrm{H}_{0}$ ditolak. Pada nilai rerata marginal, pemahaman konsep siswa yang mempunyai minat belajar tinggi diperoleh rerata 86,74 , untuk siswa yang mempunyai minat belajar rendah diperoleh rerata 67,60. Sehinggadapat disimpulkan bahwa pemahaman konsep siswa yang mempunyai minat belajar tinggi lebih baik dari siswa yang mempunyai minat belajar rendah.

3) $\mathrm{F}_{\text {hitung }} \mu 2$ vs $\mu 3=312,85>\mathrm{F}_{\text {tabel }}=6,26$ maka $\mathrm{H}_{0}$ ditolak. Pada rerata marginal diperoleh pemahaman konsep siswa yang mempunyai minat belajar tinggi yaitu 78,13, untuk siswa yang mempunyai minat belajar rendah pada rerata marginal diperoleh 67,60. Sehingga dapat disimpulkan bahwa pemahaman konsep siswa yang mempunyai minat belajar sedang lebih baik dari siswa yang mempunyai minat belajar rendah.

c. Uji komparasi ganda antar sel pada baris yang sama
Hasil uji komparasi ganda antar sel pada baris yang sama sebagai berikut.

1) $\mathrm{F}_{\text {hitung }} \mu 11 \mathrm{vs} \mu 12=38,8949>\mathrm{F}_{\text {tabel }}$ $=11,75$ maka $\mathrm{H}_{0}$ ditolak, berdasarkan hasil dari rerata marginal pemahaman konsep siswa yang mempunyai minat belajar tinggi memiliki rerata 86,92, untuk siswa yang mempunyai minat belajar sedang rerata diperoleh78,75. Sehingga dapat disimpulkan bahwa pemahaman konsep siswa yang mempunyaiminat belajar tinggi lebih baik dari siswa yang mempunyai minat belajar sedang pada metode TAI.

2) $\mathrm{F}_{\text {hitung }} 11 \mathrm{vs} .13=117,2361>\mathrm{F}_{\text {tabel }}$ $=11,75$ maka $\mathrm{H}_{0}$ ditolak. Dilihat dari hasil rerata marginal rerata siswa yang memiliki minat tinggi adalah 86,92, untuk siswa yang mempunyai minat belajar rendah rerata diperoleh 70 . Sehinggadapat disimpulkan bahwa pemahaman konsep siswa yang mempunyai minat belajar tinggi lebih baik dari siswa yang mempunyai minat belajar rendah pada metode TAI.

3) $\mathrm{F}_{\text {hitung }} 12 \mathrm{vs} 13=32,2564>\quad F_{\text {tabel }}$ $=11,75$ maka $\mathrm{H}_{0}$ ditolak, dari hasil rerata marginal diperoleh rerata siswa yang memiliki minat sedang adalah 78,75 , untuk siswa yang mempunyai minat belajar rendah rerata diperoleh 70. Sehinggadapat disimpulkan bahwa pemahaman konsep siswa yang mempunyai minat belajar sedang lebih baik dari siswa yang mempunyai minat belajar rendah pada metode TAI.

4) $\mathrm{F}_{\text {hitung }} 21 \mathrm{vs} .22=36,4694>\quad F_{\text {tabel }}$ $=11,75 \mathrm{makaH}_{0}$ ditolak. Reratasiswa yang memiliki minat tinggi adalah 86,56 , untuk siswa yang mempunyai minat belajar sedang rerata diperoleh 77,50. Sehinggadapat disimpulkan bahwa pemahaman konsep siswa yang mempunyai minat belajar tinggi lebih baik dari siswa yang mempunyai minat belajar sedang pada metode PC.

5) $\mathrm{F}_{\text {hitung }} 21 \mathrm{vs} 23=208,2573>\mathrm{F}_{\text {tabel }}=$ 11,75 maka $\mathrm{H}_{0}$ ditolak. Dilihat dari rerata marginal, rerata siswa yang memiliki minat tinggi adalah86,56, untuk siswa yang mempunyai minat belajar rendah rerata diperoleh 65,20. Sehinggadapat disimpulkan bahwa pemahaman konsep siswa yang mempunyai minat belajar tinggi lebih 
baik dari siswa yang mempunyai minat belajar rendahpada metode PC.

6) $\mathrm{F}_{\text {hitung }} 22 \mathrm{vs} 23=14,4090>\mathrm{F}_{\text {tabel }}=$ 11,75 maka $\mathrm{H}_{0}$ ditolak. Pada hasil rerata marginal, rerata siswa yang memiliki minat sedang adalah77,50, untuk siswa yang mempunyai minat belajar rendah rerata diperoleh 65,20 . Sehinggadapatdisimpulkanbahwapema haman konsep siswa yang mempunyai minat belajar sedang lebih baik dari siswa yang mempunyai minat belajar rendah pada metode $\mathrm{PC}$.

d. Komparasi ganda antar sel pada kolom yang sama

Hasil uji komparasi ganda antar sel pada baris yang sama sebagai berikut.

1) $F_{\text {hitung }} 11 \mathrm{vs} 21=0,0583<F_{\text {tabel }}$ $=11,75 \mathrm{maka}_{0}$ diterima, artinyatidak terdapat perbedaan pemahaman konsep siswa yang mempunyai minat belajar tinggi antara metode TAI dan metode PC.Sehingga dapat disimpulkan bahwa pemahaman konsep siswa yang mempunyai minat belajar tinggi pada metode TAI dan PC sama baiknya.

2) $\mathrm{F}_{\text {hitung }} 12 \mathrm{vs} 22=0,9417<\mathrm{F}_{\text {tabel }}$ $=11,75$ maka $\mathrm{H}_{0}$ diterima, artinyatidak terdapat perbedaan pemahaman konsep siswa yangmempunyai minat belajar sedang antara metode TAI dan metode PC.Sehingga dapat disimpulkan bahwa pemahaman konsep siswa yang mempunyai minat belajar sedang pada metode TAI dan PC sama baiknya.

3) $\mathrm{F}_{\text {hitung }} 13 \mathrm{vs} 23=12,56>\mathrm{F}_{\text {tabel }}$ $=11,75$ maka $\mathrm{H}_{0}$ ditolak. Dari rerata yang diperoleh siswa yang memiliki minat belajar rendah pada metode TAI adalah 70 sedangkan siswa yang memiliki minat rendah pada metode PC diperoleh rata-rata 65,20. Sehingga dapat disimpulkan siswa yang memiliki minat belajar rendahmenggunakan metode TAI mempunyai pemahaman konsep lebih baik dari siswa dengan minat belajar rendah yang menggunakan metode PC.

\section{Simpulan dan Saran}

Simpulan
Berdasarkan kajian teori dan didukung adanya analisis variansi serta mengacu pada rumusan masalah yangtelah diuraikan, maka dapat disimpulkan beberapa hal sebagai berikut:

1. Siswa yang menggunakan metodepembelajaran Team AssistedIndividuallization (TAI) mempunyaipemahaman konsep yang lebih baik dari siswa yang menggunakan metode pembelajaran Pair Checks pada pokok bahasan sistem persamaan dan pertidaksamaan linear kelas X SMAN 1 Jelimpo tahun ajaran 2018/2019.

2. Siswa yang memiliki minat belajar tinggi mempunyai pemahaman konsep lebih baik dari siswa yang memiliki minat belajar sedang dan siswa yang memiliki minat belajar tinggi mempunyai pemahaman konsep lebih baik dari siswa yang memiliki minat belajar rendah, kemudian siswa yang memiliki minat belajar sedang mempunyai pemahaman konsep lebih baik dari siswa yang memiliki minat belajar rendah pada pokok bahasan sistem persamaan dan pertidaksamaan linear kelas X SMAN 1 Jelimpo tahun ajaran 2018/2019.

3. Pada masing-masing jenis metode pembelajaran dengan minat belajar menunjukan bahwa pada metodepembelajaran Team AssistedIndividuallization (TAI) dan metodepembelajaran Pair Checks, siswa yang memiliki minat belajar tinggi mempunyai pemahaman konsep yang lebih baik dari siswa yang memiliki minat belajar sedang dan siswa yang memiliki minat belajar tinggi mempunyai pemahaman konsep yang lebih baik dari siswa memiliki minat belajar rendah, kemudian siswa yang memiliki minat belajar sedang mempunyai pemahaman konsep yang lebih baik dari siswa yang memiliki minat belajar rendah pada pokok bahasansistem persamaan dan pertidaksamaan linear kelas X SMAN 1 Jelimpo tahun ajaran 2018/2019.

4. Pada masing-masing tingkat minat belajar dengan metode pembelajaran menunjukkan, bahwa siswa dengan minat belajar tinggi dan sedang padametodeTeamAssistedIndividuallization (TAI) danmetode Pair Checks mempunyai pemahaman konsep yang sama baiknya kemudian siswa denganminatbelajarrendahyangmenggunaka $\mathrm{n}$ metode TeamAssisted Individuallization 
Jurnal Karya Pendidikan Matematika Vol 6 No 1 (2019) E ISSN : 2549 - 8401 P ISSN : 2339-2444

(TAI)mempunyai pemahaman konseplebih baik dari siswa dengan minat rendah yang menggunakan metode Pair Checks pada pokok bahasansistem persamaan dan pertidaksamaan linear kelas X SMA Negeri 1 Jelimpo tahun ajaran 2018/2019.

Saran

Dari hasil penelitian ini diharapkan dapat digunakan sebagai bahan acuan bagi guru dalam pelaksanaan kegiatan pembelajaran di kelas, dan siswa dapat berinterksi lebih aktif dalam kegiatan pembelajaran dikelas dengan menggunakan metode Team Assisted Individuallization (TAI)dan Pair Checks. Hasil Penelitian ini pula dapat digunakan sebagai bahan acuan bagi peneliti lain untuk melakukan kajian lebih mendalam dengan metode dan tinjauan yang berbeda.

\section{Daftar Pustaka}

Darmadi. (2017). Pengembangan Modeldan Metode Pembelajaran DalamDinamikaBelajarSiswa.Yogyakart a: Deepublish.

Friantini, R.N dan Winata, R. (2019). Analisis Minat Belajar pada Pembelajaran Matematika.Jurnal Pendidikan Matematika Indonesia. Vol. 4, No. 1, Hal 6-11.
Heruman. (2013). Model Pembelajaran MatematikadiSekolahDasar.Bandung: PT Remaja Rosdakarya.

Huda, M. (2015). ModelmodelPengajarandanPembelajaran.Yog yakarta: PustakaPelajar.

Shoimin,A. (2014).68Model Pembelajaran Inovatif

DalamKurikulum2013.Yogyakarta:

Ar.Ruzz Media.

Susanto, $\quad$ A.(2013). $\quad$ Teori

BelajarDanPembelajaran

DiSekolahDasar.Jakarta:Prenadamedia Group.

Syah, F. F., dkk. (2014).Pengaruh ModelTeamAssistedIndividualiztion

(TAI) DenganStructure

ExerciseMethodterhadap Hasil

Belajar. JurnalInovasiPendidikan

Kimia. Vol. 8.No. 1.

Yulita, S. R. (2016). Pengaruh Penerapan Model Pembelajaran Pair Check Terhadap PemahamanKonsep Matematika Siswa MTS. Jurnal Kajian Pendidikan dan Pengajaran.Vol. 2. No.

1. Hal. 36-44. ISSN: 2443-143 